\title{
Dossier
}

Islam en lusophonies - Islão nas lusofonias

Islam in Portuguese-speaking areas

sous la direction de / sob a direcção de / edited by

Nina Clara Tiesler

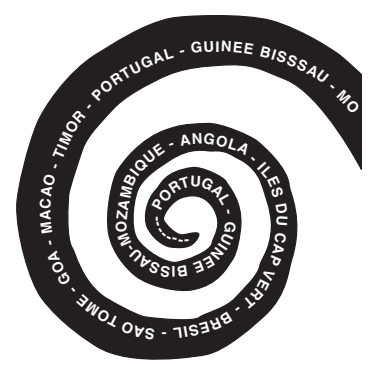




\section{ISLAM IN PORTUGUESE-SPEAKING AREAS}

\section{Historical accounts, (post)colonial conditions and current debates}

Muslims are citizens and active members of society in nearly all lusophone areas. Among the Portuguese-speaking African countries, Guinea Bissau and Mozambique have long-standing Muslim populations, while, Angola, for example, received immigrants from Islamic majority countries only recently. The Islamic presence in Portugal goes back to Gharb al-Andalus, but the contemporary Muslim communities must be understood as a postcolonial phenomenon. Brazil, East Timor and Macao, also have particular historical experiences and differing present day Muslim populations.

All cases differ significantly, but Muslims in lusophone spaces do share some similar socio-cultural point of comparison. In each case, Muslims are treated as representatives of a religious minority (except Guinea-Bissau); and in many cases Muslims represent ethnic backgrounds that differ from the dominant society. Furthermore, international migration reconfigures several lusophone fields, often leading to the increasing diversification. New transnational links have emerged among Muslims, often based on shared experiences in current national or local socio-historical contexts, on ethnicity or common language - which in many cases, is Portuguese.

\section{L'islam dans les espaces lusophones \\ Récits historiques, conditions (post)coloniales et débats actuels}

Les musulmans sont des citoyens et des membres actifs de la société dans presque tous les espaces lusophones. Parmi les pays africains de langue portugaise, la Guinée-Bissau et le Mozambique ont des populations musulmanes établies de longue date, alors que l'Angola, par exemple, n'a accueilli que récemment des immigrés de pays à majorité islamique. La présence islamique au Portugal remonte à Gharb al-Andalus, mais les communautés musulmanes contemporaines doivent être comprises comme un phénomène post-colonial. À l'heure actuelle, le Brésil, Timor oriental et Macao, possèdent également des expériences historiques particulières et des populations musulmanes différentes.

Tous les cas differrent sensiblement mais les musulmans présents dans les espaces lusophones sont comparables à bien des égards sur le plan socioculturel. Partout, sauf en Guinée-Bissau, les musulmans sont perçus comme les représentants d'une minorité religieuse, et très souvent, ils ont des origines ethniques qui diffèrent de celles de la société dominante. De plus, les migrations internationales qui reconfigurent certains domaines lusophones, conduisent souvent à une augmentation de la diversité. De nouveaux liens transnationaux ont émergé parmi les musulmans, dans les contextes nationaux et socio-historiques actuels, fondés sur l'ethnie ou la langue commune - laquelle, dans bien des cas, est le Portugais.

O Islão em espaços lusófonos.

Relatos históricos, condições (pós)coloniais e debates actuais

Os muçulmanos são cidadãos e membros activos da sociedade em quase todas as áreas lusófonas. Entre os PALOPs, Guiné-Bissau e Moçambique têm populações muçulmanas de longa data, enquanto Angola, por exemplo, recebe só 
recentemente imigrantes de países maioritariamente islâmicos. A presença islâmica em Portugal remonta a Gharb al-Ândalus, no entanto as comunidades muçulmanas contemporâneas devem ser compreendidas como um fenómeno pós-colonial. Brasil, Timor-Leste e Macau também têm experiências históricas particulares e contam com uma comunidade muçulmana cujas características diferem significativamente.

Todos os casos diferem, mas os muçulmanos nos espaços lusófonos compartilham algumas similaridades na comparação de pontos sócio-culturais. Em cada caso, os muçulmanos são vistos como representantes de uma minoria religiosa (excepto Guiné-Bissau); e em muitos casos os muçulmanos representam origens étnicas que diferem da sociedade dominante. Ademais, a migração internacional que reconfigura diversos campos lusófonos, conduz frequentemente à crescente diversificação. Novas ligações transnacionais emergiram entre muçulmanos, na base de experiências comuns em actuais contextos sócio-historicos nacionais ou locais, da etnicidade ou no idioma dominante - que maioritariamente, é o português.

M uslims are citizens and active members of society in nearly all lusophone areas. Among the Portuguese-speaking African countries, Guinea Bissau and Mozambique have long-standing Muslim populations, while, Angola, for example, received immigrants from Islamic majority countries only recently. The Islamic presence in Portugal goes back to Gharb al-Andalus, but the contemporary Muslim communities must, rather, be understood as a postcolonial phenomenon. Brazil, East Timor and Macao, also have particular historical experiences and differing present day Muslim populations.

All cases differ significantly, but Muslims in lusophone spaces do share some similar socio-cultural point of comparison, as the research questions of scholars working with these populations reflect: In each case, Muslims are treated as representatives of a religious minority (this has recently changed in the case of GuineaBissau); and in many cases Muslims represent ethnic backgrounds that differ from the dominant society. Furthermore, international migration reconfigures several lusophone fields, often leading to the increasing diversification of Muslim communities. In the course of recent migration and communication technologies, new transnational links have emerged among Muslims. These are often based on shared references to people and places left behind, on similar experiences in former colonial and today's "postcolonial condition"' (Sayyid 2006: 5), in current national or local socio-historical contexts, on ethnicity or common language - which in many cases is Portuguese.

While single scholars of different disciplines of Social Sciences, Humanities and Regional Studies have approached contemporary Muslim-related research questions in some Portuguese-speaking countries within the last decades, these countries with rather small Muslim populations lack a subsequent academic tradition of studies about Islam and Muslims, and have no specific institutional frameworks

\footnotetext{
1 The postcolonial here refers to a conceptual not just a chronically category (if meant exclusively chronically, it is here used with a hyphen: post-colonial). Sayyid names as an obvious problem that "postcolonial marks something beyond colonialism but not something intrinsic in itself", and explains: "... the "post' in the postcolonial reminds us that we have not yet arrived at something that has its own name" (Sayyid 2006: 5).
} 
which support the work of researchers in this area ${ }^{2}$. Scholarly work which mentions or focuses on contemporary Muslim communities and populations has increased since the 1990s, most of all in the area of African Studies (at least for Mozambique and partly Guinea Bissau), under the heading of Studies on Migration and Ethnic minorities (in Portugal), or in accounts on (or archived reports from within) the colonial history and in postcolonial studies. Scattered publications specialised on Muslims in Mozambique, Guinea Bissau, Portugal, East Timor and Macao reflect partly continuous individual or regional research interests, differing discursive contexts and academic traditions ${ }^{3}$, while research on Muslim communities in Brazil and, most recently Angola, must be seen as only getting started ${ }^{4}$.

\section{The Dossier}

The present volume is the first contribution which gathers academic work under the heading of Muslims in Lusophone Spaces. It is also a first trial to provide a comparative insight into the state-of-the-art of studies concerned with Muslims and Islam in Portuguese-speaking countries - and Portuguese Muslims elsewhere. It is a joint production of Lusotopie and MEL-net, an interdisciplinary, international research network on Muslims in Lusophone Spaces, hosted at the Institute for Social Sciences of the University of Lisbon (ICS-UL) 5 . The objective of this dossier responds both to the raison d'être of MEL-net, namely to inspire and facilitate academic exchange on the subject across and beyond Portuguese-speaking academic communities, as well as it responds to and realises the idea of a dossier

\footnotetext{
${ }^{2}$ For the tradition of Arab Studies in Portugal see Vakil 2003, Silva 2005 and Sidarius
} 1986.

${ }^{3}$ As for overviews and historical accounts on Muslim populations and Islamic communities in different lusophone countries, see the respective entries in CRIsTOvão 2005. References to crucial works and insight into the state-of-the-art of studies regarding the contemporary Muslim presence in Portugal, Mozambique and Brazil are provided in the articles present in this volume. An overview of bibliographical references on the subject concerning most Portuguese speaking countries is available at <www.mel-net.ics.ul.pt>.

${ }^{4}$ With some ten Master- and Doctoral theses (mostly in Anthropology) on Muslims and Islamrelated subjects during the last years and only single works of senior scholars, we came across in Brazil (special thanks to Vera Marques), the development of academic work on the subject seems to repeat the pattern which was obvious in Portugal, where the first accounts on Muslim communities in the late 1980s/early 1990s had been Bachelor- and Master-theses. As for Angola, Muslims from Sub-Saharan African countries, mainly Mali, Nigeria and Senegal, have migrated to Angola, mainly establishing in Luanda, only during the last years. A first account on Muslim communities in Luanda was presented by Fátima Viegas during the IX ${ }^{\circ}$ Luso-Afro-Brazilian Congress of Social Sciences at the University Agostinho Neto, in Luanda, Angola (28-30 November 2006). Six scholars from Brazil, Angola and Mozambique presented papers on the history and recent developments regarding Islam in these countries. Organised by Lorenzo Macagno (Univ. of Paraná, Brazil), Nina Clara Tiesler (Institute of Social Sciences, Univ. of Lisbon, Portugal) and Fátima Viegas (Univ. Agostinho Neto, Luanda, Angola), this panel on "The role of Muslim communities in processes of development and modernisation in lusophone societies", had been the third conference event of MEL-net (see description below).

MEL, Portuguese abbreviation of: Muçulmanos em Espaços Lusófonos. See <www.mel-net.ics.ul.pt> or contact<mel-net@ics.ul.pt>. 
dedicated to "Islam en lusophonie" which the editors of Lusotopie had since the year 2000.

The desire for academic exchange naturally had motivated scholars to establish, firstly individually, contacts across and beyond lusophone academic communities (joining mainly francophone and anglophone discussions). An interdisciplinary, particular discursive framework for the study of Muslim communities and Islamrelated questions did not exist in or across Portuguese-speaking academic communities. Those scholars with continuous research interests, partly educated abroad, found ways to discuss their works in international frameworks of African and Oriental, Islamic and Muslim Studies. One of such occasions to discuss studies on Islam in lusophone countries was provided by the conference panel "Islam et Monde lusophone", organised by Michel Cahen at the Congress of AFEMAM"

These occasions became more frequent with the inauguration of MEL-net, which was conceived in January 2005 and officially launched at the XIXth Congress of AFEMAM in Strasbourg, France, 7-9 July of the same year. At the same conference, the first MEL-panel took place, with seven scholars contributing papers on Muslim-related questions in the respective geographical areas. The network aims to promote international and interdisciplinary academic exchange and to open lusophone discourses on Muslim-related questions to the wider (not Portuguesespeaking) academic community by organising academic meetings, lectures, online and print publications and working groups ${ }^{8}$.

Apart from smaller meetings and virtual exchange among scholars who contribute to MEL-net, the third "pool" of papers and discussions for articles present in this volume derived from the MEL-panel "History and contemporary presence of Muslims in Lusophone Spaces: Perspectives and challenges in academic research" which took place during the Third Congress of the Portuguese Association of Anthropology9.

${ }^{6}$ AFEMAM (Association française pour l'étude du monde arabe et musulman), "Recherches et Études sur les Mondes Musulmans: un tournant? Bilans, chantiers, débats", Bordeaux, 6-8 July 2000.

Papers referring to Islam and Muslims in Portugal were presented by AbdoolKarim Vakil, Nina Clara Tiesler, Maria Abranches and Eduardo Costa Dias, with reference to Brazil by Paulo Daniel Farah, and on Guinea Bissau by Alvaro Nobrega. For details and abstracts see the section on conference panels at <www.mel-net.ics.ul.pt>.

${ }^{8}$ It does so by coordinating and providing MEL-mail (mailing list), MEL-doc (Ph.D. and Mastergroup), MEL-pub (programme of publications) and MEL-site, the network's website, where scholars can publish working papers and descriptions of their projects-in-progress. Among other activities, MEL-net is currently enlarging its bibliographical database on Muslims in Lusophone areas. Meanwhile, around 200 recipients have joined the MEL-mail, 35 international scholars have contributed in various ways to MEL-net, and have been committed to establishing this new interdisciplinary research network which is keen on integrating and connecting more scholars who work on Islam and Muslim-related questions in Portugal, Brazil, Angola, Mozambique, Guinea Bissau, Cape Verde, Macao, East Timor, as well as in Goa, Damão and Díu.

${ }^{9}$ Lisbon (ISCTE and ICS), 6-8 April 2006. Case studies on Muslims and Muslim communities in Portugal were presented by Maria Abranches, Rita Gomes Faria and Adriana Oliveira José, with reference to Mozambique by Lorenzo Macagno, and a critical account on current research perspectives on Islam, Muslims and their communities was introduced by Tiesler. For details and abstracts see the section on conference panels at <www.mel-net.ics.ul.pt $>$. 


\section{The Context of Research}

Although or especially because most scholars who have contributed as authors to this volume (or to the network) had initiated their research on Islam and Muslims before September 11, the imperative of self-critical reflection in the academies regarding the consequences of this turning point for academic research has turned obvious. Political and public discourses, as well as the situation of Muslim minorities who are subject of our discussions have changed (most visible in urban contexts) - and academic work does neither exist outside of or untouched by the dynamics of the public sphere, even less should it detach from the experience of its subject. Apart from a well established common sense to contextualise particular research results in their broader context, it is especially the desire for the most possible degree of independence which demands a consciousness of - and self-positioning in - the specific historical context which frames academic research.

The increase of research interest and academic production regarding Islam related topics in and beyond "Western" academia in the 1990s can be traced back to the historical turning point of 1989. With the end of the Cold War, one can witness an aggressive proliferation of a culturalization of political and academic discourses which had emerged in the late 1970s and had brought "Religion" back to the academic agenda. The emergence of several political movements of religiously defined groups in the early 1990 across the globe (Catholic groups in Italy, the "awakening" of the Religious Right/the Bible Belt in the USA under Reagan, the first electoral success of the FIS in Algeria, etc), mostly understood as "religious fundamentalists", nourished new inroads for research. The Rushdie Affair in 1989, the first French "headscarf-affair" in the same year, Saddam Hussein's invasion of Kuwait and the war in Bosnia put "Islam" on top of the political and academic agenda, for the first time since 1978/79 when Khomeini had taken power in Iran. Samuel Huntington (1993) published his much debated article on the Clash of Civilisations in the journal Foreign Affairs.

The turning point in academic perspectives and approaches, partly including a new obsession with "Culture" (Krämer 2000), and, as some scholars pointed out, the "erosion of analytical categories" (Werz 2004) went along with the increase of identity politics and discourses, including new manifestations of a collective Muslim subjectivity (Sayyid 2000; Tiesler 2006a, 2006b; Khan 2006; Allievi 2006).

While the turning point(s) of 1989 and global political events in the early 1990s caused new research interests in a before rather marginal field, there is no doubt upon the fact that September 11 and the new historical context marked by the "War on Terror" brought a massive explosion of public and academic interest in phenomena seen as related to Islam. The monitoring of Muslims and their community life, especially in minority contexts, is now frequently officially announced as of "prior interest" by politicians, in the media and by intelligence services. Noticeable more research funds regarding the "subject Muslims" are provided to the academies. This does not necessarily mean that the sudden increase of research activity leads to an explosion of scientific knowledge about the subject in question, as far as it concerns the experience of Muslims in contemporary societies in this specific historical context, and insight into lived Islam and Muslim community life. Rather, the entanglement of political interests under the heading of "security" with the increase of research interest and possibilities often leads to a mutual 
production of a hegemonic language which tends determining the research questions in dominant discourses ${ }^{10}$. The notion of "radicalisation" is only one example for this dynamic, wherein academic reflection at the "meta-level" often tends to lose connection to its fundamental ground: field experience and empirical data. The distance to the subjective experience of the individuals and collectives in question becomes obvious when new tendencies towards Islamic piety, the engagement of Islamic NGO's in developing countries, social movements of Muslims and the strengthening of public Islam in Western societies, new urban youth subcultures, the emergence of identity discourses which promote and are witness to a global "awakening of Muslim subjectivity" (Vakil \& Sayyid 2006), or political responses and mobilisation among Muslims against discrimination, are all easily interpreted as "evidence" for a general trend which shall justify the framing of research on Muslims (and, in the worst case, the production of its results) under the hegemonic concept of "radicalisation".

\section{Aims and Perspectives}

The development of alternative categories of analytical quality and resistance to a hegemonic language is an ambitious goal which requires ongoing critical academic debates. These can only ground on the theoretical reflection of continuous experience within the non-academic world (Claussen 2000: 27). While the present volume can not aim at achieving these goals, it is certainly inspired by the imperative. It tries providing a starting point for such discussions in our geographical area of research by presenting case studies and material which give insight into Muslim community life, lived Islam and daily life experiences of Muslims. The authors of the collection range from different disciplines, including anthropologists, historians, sociologists, scholars of Arabic literature and Comparative Studies of Religion. This first print publication which benefited from the forums provided by MEL-net gathers both authors who had published in Lusotopie before, and contributions which more directly derive from the recent academic exchange inaugurated by the network. Within the research interest of Lusotopie, the dossier privileges contributions on contemporary issues, where, naturally, national partic-

\footnotetext{
${ }^{10}$ In his revealing essay, "With Us or Against Us: The Rhetoric of the War on Terror", Yahya Birt offers an analysis of this rhetoric to see what it seeks to persuade Muslims to do, what its unspoken premises are and which categories it uses to mobilise Muslim sentiment: "After 9/11, there has been a shift in the cultural representations of Muslims towards more direct political themes and the use of terrorist violence. In particular, there has been the emergence of a shared political rhetoric, particularly between Washington and London that is central to the "war on terror" ". Birt distinguishes between a crude form of rhetoric in the "war on terror", which is summarised as "Islam versus the West" or "the clash of civilisations", and which, because it generally serves to antagonise Muslims, is not commonly used, on the one hand and a sophisticated form of the "war on terror" rhetoric on the other: "The sophisticated form argues that while suffering is found everywhere and is constant, only Muslims are highly likely to be involved in terrorism. [...] This sophisticated argument [...] replaces the crude form of 'Islam versus the West' with the more sophisticated form 'Islamism versus Americanism' " (BIRT, download 02/2007: $<$ www.yahyabirt.com/?p=57>).
} 
ularities and history have an impact in shifting constructions of the category "Muslim". This is why we were keen on including at least two accounts of most recent research in the area of history.

\section{The Contributions}

In the first section, entitled "Après les Croisades: Voyageurs musulmans et rencontres culturelles transnationales avant la lettre", Eva-Maria von Kemnitz sheds light on two differentiated categories of Muslims whose presence in Portugal in the 18th and 19th centuries is attested by documents. The period contemplated by the author covers two distinct phases, namely the epoch of Absolutism and that of Liberalism. Von Kemnitz draws the distinction on the grounds of the legal situation ascribed to Muslims and highlights the significant changes in the period as a whole in comparison to previous centuries.

Based on the translation of an auto-biographical report of an Iraqi Imam who travelled to Brazil in the second half of the 19th century, Paulo Daniel Farah offers insights into the religious practises of Muslims of African origin, and the "goals of the Imam in improving" their Islamic knowledge and routine of religious rituals. While the whole encounter was due to a coincidence (a storm had modified the route of the ship the Imam was sailing on), the stay of the Imam became significant: it had been the very first encounter with a "Muslim Other" for these groups of Muslims in Brazil and they respected and welcomed the erudite scholar from abroad as an authority.

The issue of Islamic authority is central in the second section of the volume which leads to the roots of diversity and current debates within Islam in present day Mozambican society, which, in distinction to Portugal and Brazil (the other two countries we have chosen to include in this first volume), can be seen as one of the lusophone "sociétés anciennement islamisées". Liazzat Bonate and Lorenzo Macagno contributed to this section on Islam in contemporary Mozambique, where, as elsewhere, the conceptions of Islam are diverse. As Bonate sets as a starting point, this diversity is frequently expressed by internal Muslim debate about the nature of Islamic authority and the definition of "orthodoxy", in particular with regard to religious rituals. Proceeding on an assumption introduced by Eickelman \& Piscatori (1996), Bonate explains that Islam in Mozambique is centered on the politics of "sacred authority" involving "competition and contest over interpretation of the symbols and the control of the institutions".

Macagno focuses on the late colonial phase (1961-1974) and sheds light on the internal composition and negotiations of Islamic authority in Northern Mozambique. The broader framework to discuss his material relates to the "tension between Sufism and Wahhabism" which he sets into a new proportion. In differing perspectives and based on distinguished material, both articles, however, contest common colonial and post-colonial literatures on Islam in Mozambique which have tended to uphold monolithic Orientalist views and assessed local beliefs and practices against those held in Muslim "heartlands in Arabia" and perceived as universal and immutable "orthodoxy" (Bonate).

Under the heading " 'Postcolonial people' and 'new' immigrants", the third section is on Islam in contemporary Portugal and Portuguese Muslims elsewhere 
(here: in the UK), presenting case studies of different groups of Muslims and their communities. The articles by Costa Dias, Tiesler \& Cairns, Abranches and Bastos \& Bastos focus on Muslims who came to Portugal from the former colonies Mozambique and Guinea Bissau mainly between the mid-1970s and late 1980s, while the cases presented by Gomes Faria and Mapril are about Muslims who have arrived later (mainly during the 1990s up to recent years) from countries which do not have any colonial linkage to Portugal, namely Morocco and Bangladesh.

Eduardo Costa Dias' contribution is exclusively dedicated to Muslims from Guinea Bissau and reports from his field research among marabouts and the close circles surrounding and supporting their work and daily life in Lisbon. It elaborates on different forms of - and priorities regarding - Islamic knowledge, and seeks analysing the relation of these groupings towards the institutionalised local Islamic communities and the Central mosque in Lisbon.

Maria Abranches has worked with Muslim women (mostly mothers and daughters) of both Guinean and Indian-Mozambican origin, analysing the continuous adaptation and "reconstruction of migrants' identities". Among these groups of women and girls, Abranches identifies specific strategies of identity reconstruction which are based on the negotiation between inherited references (ethno-cultural as well as religious ones) and new socio-cultural elements found in the receiving society, which can be connected with an intention of gaining more autonomy.

The articles by Tiesler \& Cairns and Bastos \& Bastos focus exclusively on postcolonial people from Indian-Mozambican origin, the group with the highest percentage of Portuguese citizens among Portuguese-speaking Muslims (apart from converts/re-verts in Portugal). Working with a particular group of young Portuguese Muslims who are organised in the only Islamic Youth Association in Portugal (CilJovem), Nina Clara Tiesler and David Cairns have realised a study which allows a comparison of cultural attitudes of these young urban Muslims with those of non-Muslim peers of similar socio-economic and educational backgrounds and found little difference. Based on quantitative and qualitative data, the authors come to the conclusion that the young people of CilJovem, who in recent years are often approached to by the public to speak about Islam and affairs as kind of "representatives" of Portuguese Muslims, are fairly typical representatives of a general middle class Lisbon youth.

The strong sense of national belonging and attachment to Portugal among postcolonial people becomes particularly clear in the article by Susana and José Gabriel Pereira Bastos. They have followed the migration trajectories of Portuguese Muslims of Gujarat origin by conducting field research in Mozambique, Portugal, and now in Leicester (UK) where 3,000-4,000 of them live. Here they held in-depth interviews among Muslim families of Gujarat origin who have lived under the colonial administration of either the Portuguese or the British, and came to the conclusion that, despite many shared references, memories and maintained ties, these two groups consider themselves to be profoundly different.

In viewing the several contributions on Muslim groups in Portugal, it becomes once again clear that Portuguese nationals of Indian-Mozambican origin, who have founded the first Islamic associations in the metropolis, are not only most established in the country, but (consequently) also less open for further long-term migration projects, in comparison to other ex-colonial settlers from Guinea Bissau (who 
have arrived later, and a lower percentage among them holds Portuguese citizenship), and to "new" immigrants, without shared colonial past, from Bangladesh and Morocco. The latter, as introduced by Rita Gomes Faria, seem to be the most mobile among these four "groups".

Based on field research in Spain and Portugal, Gomes Faria analyses her material at approaching the question whether or not Portugal could be an actual alternative to Spain or other European countries, as a destination and place for settlement for migrants from Morocco. Among several elements characterising the particular case and which could possibly opt for and facilitate the establishment in Portugal, the recuperation and imaginary of the Arab past, interestingly, seems to be the only aspect considered as helpful by the migrants. In contrary to other (more established) non-Arab Muslim groups, for whom the recent positive turn in public and political discourse regarding Gharb al-Andalus does not seem to be significant at the level of everyday life, many Moroccan migrants have developed a discourse of proximity to Portuguese culture, using the Arab Portuguese past to explain an easiness to adapt to their new environment. Their statement, "This is like Morocco", at the same time points to the difficulties to achieve the necessary and desired economic objectives. Consequently, the real aim of their migration project remains reaching France or the Netherlands, in and their words: "the real Europe".

Gomes Faria concludes that the existence of established Islamic infrastructures (mostly managed by Portuguese-speaking Muslims) does not exercise any gravitational pull for Moroccan migrants. Their religious life rather tends to a course of privatisation. While other articles of this section on the migration-caused Muslim presence in Portugal examine cultural changes and/or eventual shifts in concepts of belonging and identity constructions, the significance of religious life and rituals is central in José Mapril's article on Muslims from Bangladesh in Lisbon. Based on ethnographic field work, Mapril examines a ceremony called milad that is performed on certain occasions such as the opening of a shop or the inauguration of a house. In opposition to current prominent theories in migration and religious studies which highlight transformations in religious practices and religiosity among Muslim migrants, the author prefers to focus on the relation between Islam and migrants' experiences - and not on the question of continuities and/or transformations in the first place. He argues in favour of a kind of phenomenology of Islam, "where one can see how Islam is lived by migrants; and how it helps our interlocutors to think about the world they live in."

Gaining a new "world view" is one of the experiences which converts in São Paulo perceive as entirely positive, explains Vera Lucia Marques. This is how the last section of the volume leads again to Brazil where the current Muslim presence is mainly constituted by migrants from Syria and Lebanon who have established themselves and the main -by Islamic associations since the end of the Second World War. Recently, the Islamic communities in São Paulo experience an expansion through the conversion (in Islamic terms: re-version) of Brazilians without Muslim family roots. Marques introduces the goals and key challenge for converts who balance their membership in the Muslim community, promoting its group oriented values, while simultaneously maintaining their "individual identity". As such, the last theme of this dossier calls attention to the phenomenon of conversion 
to Islam, which has particularly increased since September 11 (most accounts point to a triplication of numbers in comparison to former years) in Europe, the USA, and in the Portuguese-speaking countries which we could include in this volume ${ }^{11}$.

February 27, 2007

Nina Glara TIESLER

Universidade de Lisboa

Instituto de Ciências Sociais

\section{Bibliography}

Allievi, S. 2006, "How and Why 'Immigrants' became 'Muslims'”, ISIM Review (Leiden), 18, Autumn 2006: 37.

Cluaussen, D. 2000, Aspekte der Alltagsreligion. Ideologiekritik unter veränderten gesellschaftlichen Verhältnissen, Frankfurt am Main, Verlag Neue Kritik ("Hannoversche Schriften", Bd. 3).

CRistovão, F. ed., 2005, Dicionário Temático da Lusofonia, Lisbon, Associação de Cultura Lusófona, Instituto Camões.

Eickelman, D. \& J. Piscatori 1996, Muslim Politics, Princeton (New Jersey), Princeton University Press.

Huntrngton, S. 1993, "The Clash of Civilisations”, Foreign Affairs (Palm Coast, Floride), 1993, LXXII (3): 22-49.

Khan, S. 2006, "Muslims!", in N. Ali, V.S. Kalra \& S. Sayyid, eds, A Postcolonial People. South Asians in Britain, London, Hurst \& C: 182-187.

Krämer, G. 2000, "On Difference and Understanding: The Use and Abuse of the Study of Islam”, ISIM Newesletter, 5, June 2000: 6-7.

SAyyid, S. 2000, "Beyond Westphalia: Nations and Diasporas", in B. Hesse, ed., Unsettling Multiculturalism, London, Zed Press.

2006, "Introduction: BrAsians: Postcolonial People, Ironic Citizens", in N. Ali, V.S. Kalra \& S. Sayyid, eds, A Postcolonial People. South Asians in Britain, London, Hurst \& C': 1-10.

Siddrius, A. 1986, "Islão e Arabismo na Península Ibérica", Actas do XI Congresso da União Europeia de Arabistas e Islamólogos, 1982, University of Évora.

Silva, M. C.d. 2005, "O sentido dos 'árabes no nosso sentido. Dos estudos sobre árabes e sobre muçulmanos em Portugal, Análise Social (Lisbon, ICS), XXXIX (173), 2005: 753-806.

Tiesler, N.C. 2006a, "Back to the Roots? A Busca da experiência subjectiva na selva das políticas da identidade", in R. Sarró \& A. Lima, eds, Terrenos Metropolitanos, Lisbon, ICS: 155-176.

2006b, Muslime in Europa. Religion und Identitätspolitiken unter veränderten gesellschaftlichen Verhältnissen, Münster-Hamburg-Berlin-Wien-London, LIT-Verlag.

"The kind offer for collaboration which MEL-net has received from Lusotopie was fundamental for the realisation of this first collection of articles on Muslims in lusophone spaces. Having taken the role of the guest editor, I may take the liberty to say, in the name of the authors and the network, that we owe Michel Cahen and the crew of Lusotopie a great depth of gratitude. I am equally grateful to Éric Morier-Genoud and Lorenzo Macagno for the precious help they provided. Acknowledgements must also be directed to the members of the Executive Committee of MEL-net, Maria Abranches, Paulo Daniel Farah, José Mapril and AbdoolKarim Vakil, and to other colleagues, for their dedication in establishing and running the network, for the travels they have coped with to contribute to our conferences, for the ongoing inspiring discussions which are reflected in this volume. Above all, special thanks to all authors for their readiness, expertise, efforts, and patience. 
VAKIL, AK. 2003, "The Crusader Heritage: Portugal and Islam from Colonial to Postcolonial Identities", in R.S. Peckham ed., Rethinking Heritage: Cultures and Politics in Europe, London, I.B. Tauris: $29-44$.

Vakil, AK. \& SAYYID, S. 2006, "Its politics, stupid", The Muslim Neres (Harrow, UK), 27 October 2006 (special supplement): 9.

Werz, M. 2004, "The Fate of Emancipated Subjectivity", in J. Abromeit \& W. Mark, eds, Herbert Marcuse. A Critical Reader, New York, London, Routledge: 209-229. 


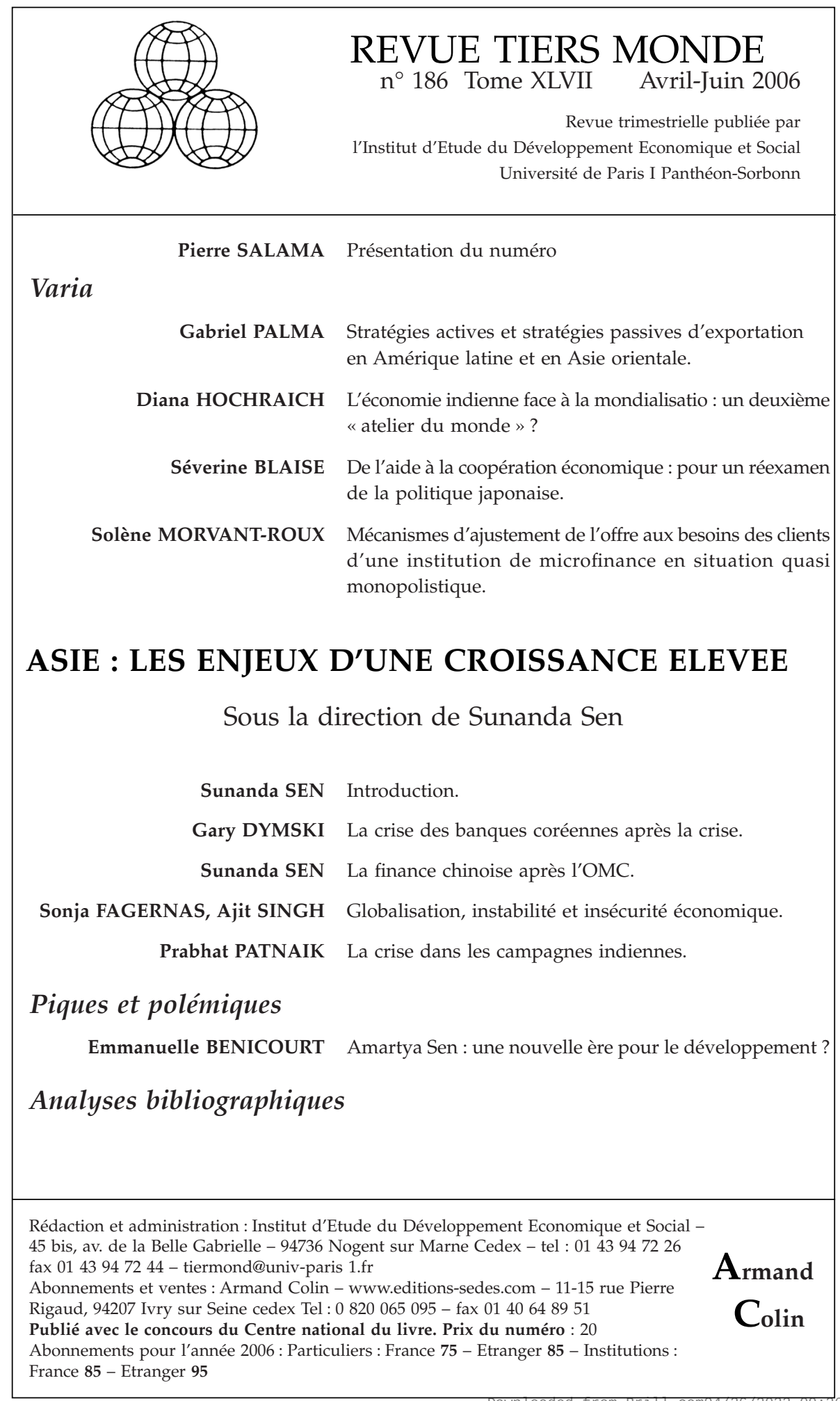

